\title{
Thomas Hobbes ja pelon taloustiede
}

\section{Mikko Jakonen}

\begin{abstract}
Abstrakti
Thomas Hobbesia ( I588-1679) pidetään usein yhtenä "kapitalismin isistä". Näkökulma on kuitenkin sinänsä ongelmallinen, että Hobbes ei juurikaan kirjoittanut pääomista tai tuotannosta. Hänen poliittinen ajattelunsa oli vastakkaista Englannin nousevan porvariston pyrkimyksille toteuttaa vero- ja kauppavapaus. Hobbes piti aikansa Alankomaita huonona esimerkkinä pääoman ja vapauden liitosta.

Kysymys omistuksesta löytyy kuitenkin Hobbesin yhteiskuntateorian perustasta. Kuuluisassa "luonnontilassa" ei voi Hobbesin mukaan olla omistusta, koska vain oikeusjärjestelmä yhdessä väkivallan monopolin kanssa kykenee takaamaan sen. Hobbes kannustaa ihmisiä tuottavaan elämään ja näkee valtion tehtävänä sellaisten puitteiden luomisen, joissa tuottava elämä on mahdollista.

Hobbesin suhtautumisen työhön, omistukseen ja markkinoihin tekee erityisen mielenkiintoiseksi hänen näkemyksensä, jonka mukaan yhtään merkittävää valtiota ei ole koskaan rakennettu muulle perustalle kuin pelolle.Tällä hän tarkoittaa erityisesti luonnontilassa vallitsevaa keskinäistä pelkoa, joka tekee yksityisomistuksen mahdottomaksi.Tämän lisäksi Hobbes esittää, että myös yhteiskunnassa pelko on keskeinen hallintaväline. Järjestäytyneessä yhteiskunnassa pelko ei kuitenkaan kohdistu toisia kansalaisia kohtaan, vaan suvereenia hallitsijaa kohtaan. Omistamiseen liittyen Hobbes esittääkin, että suvereenilla on tarvittaessa oikeus viedä kansalaisen omaisuus, jos tarve niin vaatii.

Tarkastelen tässä artikkelissa Hobbesin näkemyksiä omistusoikeudesta, työstä ja tuotannosta. Jäsentävänä näkökulmana toimii Hobbesin teoria tunteista ja erityisesti pelosta. Tästä perspektiivistä käsin huomataan, että Hobbesin talouspoliittinen teoria ei itsestään selvästi sovellu liberaalin tai uusliberaalin kapitalismin perustaksi.
\end{abstract}




\section{Johdanto}

Nykyisissä filosofisissa, politiikan teoreettisissa ja poliittisen ajattelun historiaa koskevissa tutkimuksissa Thomas Hobbesin (1588-1679) poliittista filosofiaa ei tavallisesti tarkastella taloudellisista lähtökohdista käsin. ${ }^{1}$ Huolimatta Hobbesin talousfilosofiaa käsittelevän tutkimuksen niukkuudesta ${ }^{2}$ olisi kuitenkin virheellistä väittää, että Hobbesia ei ole lainkaan yhdistetty taloutta koskeviin keskusteluihin. Asia on oikeastaan päinvastainen. 1900luvulla Hobbes on varsin yleisesti nimetty yhdessä John Locken (16321704) ja Adam Smithin (1723-1790) kanssa yhdeksi liberalismin ja siten myös kapitalismin "isistä". ${ }^{3}$

Näkökulma on kuitenkin monessa mielessä ongelmallinen ja suhtautuminen Hobbesin talouspoliittisiin näkemyksiin on vaihdellut runsaasti kautta tulkinta- ja vastaanottohistorian (Taylor 2010). Vaikka Hobbesin ja Locken teoriat valtiosta ja taloudellisesta toiminnasta ovat monin tavoin samankaltaisia, on huomattava, että Hobbes ja Locke voidaan nähdä myös kiistakumppaneina. ${ }^{4}$ Locke ei ollut valmis hyväksymään Hobbesin näkemystä absoluuttisen vahvasta valtiosta. Sama koskee Hobbesin suhdetta Adam Smithiin.

1900-luvun alkupuolella voimistuneen tulkinnan mukaan Hobbesia pidetään niin englantilaisen kuin analyyttisen filosofian klassikkona. Mahdollisesti juuri tästä johtuen Hobbesin poliittis-taloudellinen oppi on pitkään yhdistetty liberaaliin kapitalismiin, sillä hänet on nähty yhtäältä William Pettyn (1623-1687) ja toisaalta ranskalaisten fysiokraattien näkemyksille läheisenä ajattelijana. Toisaalta hänet on myös liitetty merkantilismiin (Taylor 2010, 416-417.) Tämän lisäksi Hobbesia on kutsuttu myös eksplisiittisesti poliittisen taloustieteen perustajaksi. Monet politiikan ja talouden tutkijat ovat tehneet tämän huomion korostaen Hobbesin erityislaatuista asemaa modernin taloudellisen kehyksen hahmottelijana. (Vinnicombe \& Staveley 2002, 691.)

Näissä tulkinnoissa Hobbesia ei nähdä ainoastaan valtion taloudellisen ja poliittisen organisaation rakentajana, vaan häntä pidetään myös metodologisesti modernin hyötyjen ja haittojen laskemiseen perustuvan taloudellisen ajattelun hahmottajana. Hobbesin analyysistä ja synteesistä (tai resoluutiosta ja kompositiosta) muodostuva, geometrian innoittama menetelmä nähdään keskeisenä myöhemmälle länsimaiselle poliittiselle taloustieteelle. 
Vaikutus näkyy aina 1900-luvun peliteorioihin ja rationaalisen valinnan teoriaan asti. Näin ollen Hobbesin teorian nähdään toimivan sekä poliittisena että taloudellisena mallina, mutta myös metodologisena perustana modernille kapitalistiselle ajattelulle.

Tässä artikkelissa Hobbesin poliittista filosofiaa tarkastellaan poliittisena taloustieteenä, joka kuitenkin poikkeaa varsinaisesta 1700-luvulla syntyneestä markkinoihin ja vaihtoon perustuvasta poliittisesta taloustieteestä. Viimeksi mainitun merkittävimpinä teoreetikkoina voidaan pitää skottilaisen valistuksen filosofeja kuten Adam Smithiä ja David Ricardoa (1772-1823). ${ }^{5}$ Hobbes ei itse koskaan käyttänyt termiä political economy, vaikka käsite oli tunnettu jo vuonna 1615 Antoine de Montchrestienin (1575-1621) kirjoittaman Traicté de l'Economie politique -teoksen perustalta (Montchrestien 1889). ${ }^{6}$

Hobbesin merkitys myöhemmälle poliittiselle taloustieteelle löytyy niistä samoista tekijöistä, joista hänen varsinainen poliittinen teoriansa koostuu. Hobbesia on usein kutsuttu järjestyksen filosofiksi ja hänen keskeistä poliittista kysymystään järjestyksen ongelmaksi. ${ }^{7}$ Nähdäkseni tämä lähtökohta on pätevä ja se tuo myös taloudesta käytävään keskusteluun perustavan orientaation. Olennainen kysymys on tällöin se, millaisissa olosuhteissa taloudellinen toiminta ylipäätään on mahdollista.

Järjestyksen ongelmaan liitetään tavallisesti kysymys irrationaalisesta ja rationaalisesta toiminnasta. Hobbesin mukaan järjen tulee olla kaiken poliittisen toiminnan perusta. Olisi kuitenkin virheellistä nähdä Hobbesin poliittinen ja taloudellinen filosofia yksinomaan järkeä korostavana teoriana. Itse asiassa Hobbes oli yksi ensimmäisistä ja jälkikäteen katsottuna tärkeimmistä 1600-luvun politiikan teoreetikoista, joka tutki ja tunnusti tunteiden merkityksen ja keskeisyyden kaikessa inhimillisessä toiminnassa. (Gert 1989; Gert 1996; Esposito 2000.) Keskeisin ja tärkein tunne Hobbesille on pelko. Kysymys tästä ihmisluontoa ja -yhteisöä määrittelevästä tunteesta kietoutuu tiiviisti järjestyksen kysymykseen: Hobbesin mukaan pelko aiheuttaa sekasortoa, mutta se on myös edellytys järjestäytyneen yhteiskunnan muotoutumiselle ja hallinnalle.

Tarkastelen tässä artikkelissa ${ }^{8}$ Hobbesin poliittista taloustiedettä ja politiikan teoriaa pelon taloustieteenä. Lähden liikkeelle luonnontilan eli niin sanotusta väkijoukon ${ }^{9}$ ongelmasta, joka on nimenomaan epäjärjestyksen ongelma. Teen aluksi yleisiä huomioita luonnontilan käsitteestä, minkä 
jälkeen tarkastelen lähemmin Hobbesin teoriaa tunteista ja pelosta. Tämän jälkeen pohdin lyhyesti taloudellisen toiminnan mahdottomuutta luonnontilassa. Toisessa luvussa käännän huomion kysymykseen valtiosta ja pelon taloustieteestä. Tarkastelen ensiksi pelon logiikassa tapahtuvaa muutosta siirryttäessä luonnontilasta yhteiskuntaan. Tämän jälkeen käyn läpi niitä näkemyksiä, joita Hobbes esittää työn ja tuotannon suhteesta valtion elinvoimaan. Viimeiseksi pohdin kysymystä valtion ja yksityisten rikkauksien välisestä suhteesta. Lopuksi vedän yhteen näkemyksiä Hobbesin poliittisen taloustieteen suhteesta pelkoon.

\section{Luonnontila: taloudellisen toiminnan umpikuja}

\section{Yleisiä huomioita luonnontilasta}

Vaikka luonnontilan (state of nature) käsite ei ole varsinaisesti Hobbesin kehittämä, on hänen tulkintansa siitä yksi kuuluisimmista ja tärkeimmistä modernin politiikan teorian muotoiluista. ${ }^{10}$ Luonnontilan käsitettä Hobbesin tuotannossa on käsitelty runsaasti (katso mm. Angoulvent 1992; Tricaud 1988 ja Thornton 2005), eikä tässä artikkelissa ole mahdollista tarkastella sen kaikkia ulottuvuuksia. Muutamia yleisiä suuntaviivoja on kuitenkin tarpeellista hahmottaa.

Ensiksikin, luonnontilan käsite on teoreettinen abstraktio. Huolimatta muutamista viittauksista Amerikan intiaaneihin, joiden Hobbes oletti elävän luonnontilassa ( $E L$, I, 12; L XII, 11), Hobbes ei puhu joskus todella vallinneesta ihmisten tilasta. Kyse on teoreettisesta konstruktiosta, jonka tarkoituksena on rakentaa negaatio tarjotun poliittis-taloudellisen ratkaisun vaihtoehdoksi. Luonnontilan käsite muodostaa Hobbesille siis järjestäytyneen yhteiskunnan vastakohdan. ${ }^{11}$

Toiseksi, vaikka luonnontila on konstruoitu negaatio, se on myös tavoiteltavan yhteiskunnan premissi. Hobbesin poliittisen filosofian ratkaiseva käännekohta tapahtuu siirtymässä, jossa luonnontila päättyy ja valtio alkaa. Tästä huolimatta, luonnontilaa yhteiskunnan premissinä ei hylätä missään vaiheessa, sillä luonnontilan käsite perustuu ihmisluonnon (human nature) käsitteelle.

Ihmisluonnon käsitteen uudelleenmäärittely oli varhaismodernin 
filosofian tärkeimpiä saavutuksia. Koko sosiaalisen ja poliittisen järjestyksen pohdinta palautettiin ihmisen lajityypillisiin piirteisiin. Ihmisluonnon käsitteellä vastustettiin erityisesti skolastista, aristoteelisesti ymmärrettyä ihmisluonnon käsitystä.

Luonnontila on kuva ihmisistä vailla yhteistä valtaa ja yhteiskuntaa (commonwealth). Luonnontilassa ihmiset tekevät egoistisia ratkaisuja turvatakseen oman elossa säilymisen (self-preservation), joka on luonnollisesti tärkein asia ihmiselle. Säilyäkseen hengissä ihmiset ovat valmiita varastamaan, pettämään tai jopa tappamaan lähimmäisensä. Siksi luonnontilasta ja ihmisluonnosta juontuva perustava premissi on epäluottamus toisia ihmisiä kohtaan ja tarve turvata oma elossa säilyminen millä tahansa keinolla. Tätä ensisijaista luonnonoikeutta (natural right) ihminen ei voi koskaan luovuttaa pois. Hobbes korostaa, että ihmiset eivät perusta yhteiskuntaa yhteisen hyvän vuoksi, vaan oman itsensä takia. (DC I, 2.) Tästä ajatuksesta seuraa kuuluisa oman edun (self-interest) käsite, jonka vuoksi Hobbes on usein yhdistetty liberaaliin laissez-faire-politiikkaan ja Homo oeconomicus -ajatteluun. (Taylor 2010, 418; Labiano 2000.)

Kolmanneksi, vaikka Hobbesin lähtökohtana on ihmisluonto, kyse ei ole täysin muuttumattomasta ihmisluonnosta. Luonnontilan kuvausta on aivan liian usein luettu eräänlaisena perisynnin metaforana. Tässä mielessä Hobbesin näkemys ei juuri eroa Augustinuksen vastaavasta, jonka mukaan ihminen on luonnoltaan syntinen olento, joka ei voi vapautua synnistä muun kuin kasteen ja uskon kautta. Katolisesta uskosta ja Augustinuksen teologiasta poiketen Hobbes näkee ihmisluonnon kuitenkin tiedon ja politiikan avulla muokattavana ja muuttuvana. Ihmistä voidaan muuttaa, kunhan vain tunnetaan ihmisluonnon, siis ihmisruumiin ja -mielen liikkeiden perustavat lainalaisuudet.

Ihmismielen perinjuuriseen tuntemiseen johtaa materialistinen ontologia, joka perustuu uudelleen määritellyille liikkeen ja materian käsitteille. Hobbesin mukaan maailma ei ole mitään muuta kuin liikkuvaa materiaa, minkä seurauksena myös ihmismieli on materian liikkeistä ja niiden havainnoista muodostunut kokonaisuus. Siksi ihmistä on mahdollista ohjata muokkaamalla aistihavaintoa ja sitä jäsentäviä käsityksiä (ymmärrystä). Ainoat rajat muuntelulle muodostavat materian itsensä asettamat rajoitteet.

Neljänneksi ja viimeiseksi on tärkeää ymmärtää, että luonnontilan ongelmat johtuvat nimenomaan ihmisyhteisön sosiaalisesta organisaatiosta. 
Hobbes kutsuu luonnontilassa elävää tai luonnontilaisesti käyttäytyvää ihmisyhteisöä väkijoukoksi (multitude). Väkijoukon käsite juontuu varhaismoderniin poliittiseen kieleen yhtäältä antiikin filosofiasta, jossa termit hoi polloi, plethos ja ochlos viittasivat poliittisesta yhteisöstä ja päätöksenteosta ulossuljettuihin Moniin eli pääasiassa köyhiin. Toisaalta termi on varsin yleinen Raamatun kielessä ja sitä käytettiin runsaasti renessanssiteoreetikkojen ja varhaismodernien poliittisten pamfletistien kirjoituksissa. Hobbesilla väkijoukon käsite muodostuu kuitenkin aivan uudenlaiseksi teoreettiseksi käsitteeksi. (Jakonen 2013, 48-72.)

Väkijoukolla Hobbes viittaa sekasortoiseen, järjestäytymättömään, vallattomasti ja epämääräisesti liikkuvaan, tunteelliseen ja kiihkeään, hirviömäiseen ihmisjoukkoon. Väkijoukkoa määrittelee siis erikoislaatuinen paradoksaalisuus. Yhtäältä, kaikki ihmiset ovat luonnollisilta kyvyiltään samanlaisia, sillä ihmisluonto on kaikille sama. Hobbesin mukaan kukaan ihminen ei ole toista etevämpi luonnostaan: toinen voi olla älykkäämpi, mutta toinen on fyysisesti vahvempi. (L, XIII, 1.) Toisin sanoen, kaikki ihmiset ovat luonnontilassa tasa-arvoisia: ihmisiä ei voida jakaa hyviin ja huonoihin kuten esimerkiksi Aristoteles teki filosofiassaan. Koska ihmisyhteisö kuitenkin käytännössä muodostuu erilaisista poliittisista ryhmittymistä, uskonnollisista lahkoista, perhekunnista, kauppakomppanioista ja niin edelleen, on kysyttävä, mihin tämä kykyjen tasa-arvoisuus johtaa. Hobbesin mukaan seurauksena on luonnollisen yhteiskunnan mahdottomuus, sillä väkijoukossa yksikään ihminen ei tyydy hänelle annettuun asemaan. Toisin sanoen, kykyjen tasavertaisuudesta on väistämättömänä seurauksena "kaikkien sota kaikkia vastaan" ( $L$, XIII, 9). Tilanne voidaan korjata ainoastaan luomalla keinotekoinen (artificial) valtio.

Väkijoukon perustavana ongelmana on nimenomaan ihmisluonnon ongelma: väkijoukossa ei ole minkäänlaisia keinotekoisia rajoitteita ihmisten toiminnalle. Luonnontilassa mikään ei ohjaa tai järjestä ihmisten luonnollisia liikkeitä. Tästä johtuen eläminen sekavassa ja epävarmassa väkijoukossa lisää ihmisten epäluottamusta toisiinsa, mikä puolestaan ruokkii moraalittomuutta ja häikäilemätöntä oman edun tavoittelua toisten kustannuksella. Väkijoukossa kaikki ihmisyhteisöä järjestävät yksilöiden väliset hierarkiat ovat vain hetkellisiä. Syy egoististen yksilöiden häikäilemättömään toimintaa luonnontilassa ei siis ole ihmisluonnon peruuttamaton pahuus, vaan väkijoukko: sekava, rajoittamaton ja järjestäytymätön 
"luonnontilainen" ihmisyhteisö.

Hobbes tunteista ja pelosta

Luonnontilassa ihmisen elämä on Hobbesin kuuluisan muotoilun mukaan "yksinäinen, kurja, häijy, raaka ja lyhyt" (L XIII, 9, s. 124). Kykyjen tasa-arvoisuudesta johtuen luonnontila muistuttaa sotatilaa, jossa kaikki ovat sodassa kaikkia vastaan. ${ }^{12}$ Luonnontilan sotatila ei kuitenkaan ole aktuaalista taistelua, vaan pikemminkin epämääräinen jännittynyt tilanne, jossa "kaikki on mahdollista". Luonnontila ei ole jatkuvaa yksilöiden kamppailua toisiaan vastaan, vaan tilanne, jossa jännitteet voivat mahdollisesti eskaloitua konflikteiksi ja konfliktit levitä koko yhteisöön. Räjähdysherkkä tilanne vaikuttaa ihmisten käyttäytymiseen ja edesottamuksiin. Siksi luonnontilaa määrittelee epävarmuus ja pelko.

Ihmiseen kaikkein voimakkaimmin vaikuttavana tunteena pelko on Hobbesin poliittisen filosofian tärkeimpiä rakennuskappaleita. Pelon määritelmä perustuu Hobbesin mielenfilosofiaan, jonka peruskäsitteitä ovat kaksi liikettä, halu (appetite) ja vastenmielisyys (aversion). Halu saa ihmisen liikkumaan tai tuntemaan vetoa sellaista ulkoista kappaletta (tai kappaleen aiheuttamaa mielikuvaa) kohden, joka vaikuttaa lisäävän henkilön mahdollisuuksia itsesäilytykseen, siis elämään. Vastenmielisyys on puolestaan liikettä pois sellaisista kohteista, jotka uhkaavat elossa pysymistä. $(L, V I .)^{13}$

Koska maailma ei ole Hobbesin mukaan mitään muuta kuin materian liikettä, toimii myös mieli - joka itsessään on pelkkää liikettä - suhteessa näihin ulkoisiin liikkeisiin. Ihmisen aistielimet välittävät tietoa ulkoisista materian liikkeistä ihmisruumiin sisäisiin osiin (aivoihin). Aivoissa aistihavainnon aiheuttama liike tai informaatio tulee käsitellyksi siten, että tietyt liikkeet aiheuttavat tietynlaisia ihmislajille tyypillisiä tuntemuksia, jotka kuitenkin varioivat yksilöllisen kokemuksen ja henkilökohtaisen muistin perusteella. ${ }^{14}$ Tämä psykologinen periaate noudattaa uuden ajan alun luonnonfilosofian perusnäkemystä, jonka mukaan kaikki laadulliset havainnot ovat aina subjektiivisia.

Sosiaalisuudella ja kokemuksillamme muiden ihmisten havaituista reaktioista suhteessa omiin reaktioihimme on vaikutusta tunteiden muodostumisessa. Koska tunteiden perustavana tehtävänä on viestiä elämän voimia lisäävästä tai vähentävästä liikkeestä, ne toimivat merkkeinä ja informaationa 
mielenliikkeistämme niin itsellemme kuin toisillekin. Tunteiden ilmaisut ovat yksi tärkeimmistä sosiaalisen kudoksen sidosaineista.

Hobbesille tärkein ja perustava tunne on siis pelko. Mitä pelko sitten on? Leviathanissa Hobbes määrittelee sen seuraavasti: "Vastenmielisyys, johon liittyy ajatus objektin tuottamasta vahingosta, on PELKOA" (L, VI, 16. s. 68). Olennaista Hobbesin pelon määritelmää pohdittaessa on huomata, että pelkoa aiheuttava objekti ei välttämättä ole vain jokin yksinkertainen kappale, kuten vaikkapa ase. Pelkoa aiheuttava objekti voi olla myös jokin monimutkainen aistihavaintoon vaikuttava kokonaisuus, kuten vaikkapa "valtio". Olennaista on, että tunteita tunteva subjekti kykenee nimeämään ymmärryksensä, kulttuurisen kontekstinsa ja kielellisen käsitteellistämiskykynsä perusteella objektin aistihavaintojensa lähteeksi, vaikka objekti ei olisikaan reaalinen. Näin esimerkiksi palava pensas voidaan ymmärtää Jumalaan liittyvänä aistihavaintona ja merkkinä, minkä vuoksi se voi esimerkiksi aiheuttaa Jumalan pelkoa.

Pelko saa kuitenkin toisenlaisia piirteitä, kun se ilmenee väkijoukossa (multitude). Tunteilla on aina sosiaalisia vaikutuksia ja myös ihmisyhteisöstä voi välittyä tietynlaisia tunteita. Niin kauan kuin pelon syy on yleisesti tunnettu, ihmisyhteisö pystyy käsittelemään tuota pelkoa, eikä sen liikehdintä muutu kaoottiseksi. Tuntemattomasta syystä aiheutuva pelko johtaa kuitenkin paniikkiin ja kaaokseen. Näin tapahtuu erityisesti suurissa väkijoukoissa. ${ }^{15}$

Väkijoukossa yhden ihmisen "rationaalinen" pelko (kohde tunnettu ja tiedetty) voi siis aiheuttaa mekaanisen ketjureaktion, jossa pelon varsinainen syy häviää ja ihmiset reagoivat toisten ihmisten pelosta kertovaan liikkeeseen, joka aiheuttaa edelleen kaoottista liikettä. Mimesis eli jäljittely on tyypillistä ihmisyhteisölle ja se liittyy oppimiseen, mutta panikoinnin vuoksi jäljittelyllä voi olla myös kohtalokkaat seuraukset ihmisyhteisölle. ${ }^{16}$ Jäljittely ei liity ainoastaan paniikkiin, vaan pelkoon yleisemminkin. Luonnontilassa yksilön itsesäilytys on tärkein motiivi toiminnalle. Luonnontilassa yksilö pyrkii jatkuvasti hankkimaan asioita, jotka vahvistavat hänen hengissä pysymistään. Vallan ja voiman tavoittelu lähtee siis liikkeelle omaan heikkouteen liittyvästä pelosta. Anarkian tilassa (hallinnon puuttuessa ${ }^{17}$ ) yksilö turvaa oman olemassaolonsa hankkimalla hallintaansa mahdollisimman paljon resursseja, valtaa ja voimaa, joilla hän voi suojella itseään. Tähän liittyy myös toisten ihmisten jäljittely, sillä menestyviä ja 
voimakkaita ihmisiä jäljitellään helpommin kuin heikkoja. Luonnontilassa ihmiset pyrkivät turvaamaan oman olemassaolonsa tavoittelemalla toisten ihmisten hallussa olevia asioita, sekä myös toisten ihmisten, ihmisryhmien tai valtioiden ominaisuuksia $(L$, XXIX, 13,14$)$. Tämä johtaa omistuksen ongelmaan ja kysymykseen talouden mahdollisuudesta luonnontilassa.

\section{Talouden mahdottomuus luonnontilassa}

Jäljittely ja pelko johtavat luonnontilan perustavaan ongelmaan. "Luonnontilassa" menestyviä ihmisiä, heidän käyttämiä asioita ja ominaisuuksia halutaan itselle oman itsen suojelemiseksi. Tämä aiheuttaa väistämättä varkauksia ja rikoksia, joista ei luonnontilassa oikeusjärjestelmän puuttuessa kuitenkaan rangaista. Siksi luonnontilassa vallitsee jatkuva epäluulo ja epäluottamus. Luonnontilassa ei ole mitään pysyvää: henkilön A hallussa pitämät asiat voivat olla huomenna henkilön B hallussa. Luonnontilassa vallitsee vahvimman oikeus, mutta vahvin ei välttämättä ole se, jolla on eniten fyysistä voimaa. Älykkyys, sosiaalinen maine, juonikkuus ja neuvokkuus ovat yhtäläisiä voimia. Luonnontilassa ei ole pysyviä hierarkioita: kaikki yhteisölliset asemat horjuvat ja heiluvat. Luonnontilaista ihmisyhteisöä eli väkijoukkoa määrittelee jatkuva, epämääräinen liike.

Koska luonnontila on prekaarisuuden, epävarmuuden ja epäluottamuksen tila, Hobbesin mukaan kaikki pitkäjänteinen taloudellinen toiminta näyttäytyy siellä mahdottomalta. Leviathanissa Hobbes tähdentää kuinka:

...kaikki se siis aiheutuu myös ajasta, jolloin ihmiset elävät ilman muuta turvaa kuin minkä heidän oma voimansa ja kekseliäisyytensä heille hankkii. Sellaisessa olotilassa ei ole sijaa yrittelijäisyydelle (industry), koska sen hedelmä on epävarma; ei siis myöskään maanviljelystä; ei merenkulkua eikä meritse tuotavien tavaroiden käyttöä; ei kunnollisia rakennuksia; ei kulkuneuvoja eikä laitteita voimaa vaativiin kuljetuksiin; ei tietoa Maan pinnasta; ei käsitystä ajasta; ei taiteita; ei oppia; ei yhteisöjä; ja mikä pahinta, vallitsee ainainen pelko ja väkivaltaisen kuoleman vaara: ja ihmisen elämä on yksinäinen, kurja, häijy, raaka ja lyhyt. ( $L$, XIII, 9, s. 123-124.) 
Luonnontilassa vallitsee epävarmuus, epäluottamus ja pelko. Ilman luottamusta $^{18}$ kaupankäynti on mahdotonta. Ilman luottamusta ei ole mahdollista aloittaa yhteisiä projekteja, sillä jokainen pelkää toisen petosta. Ilman luottamusta ei yksinkertaisesti ole olemassa yhteistyötä, vaihdantaa tai markkinoita. Luonnontilassa tehtävä työ on täysin yksilöllistä ja eläimellistä omasta hengissä selviämisestä huolehtimista, vaikka siihen liittyisikin inhimillisiä piirteitä, kuten talojen, aseiden ja muun "omaisuuden" hankkimista. Luonnontilassa tehtävän työn hedelmät ovat yhtä katoavia kuin niitä tuottava ihminen.

Luonnontilan tärkein ongelma onkin omistuksen ongelma. Koska luonnontilassa ei ole oikeutta, siellä ei ole myöskään "omistusta, ei määräysvaltaa, ei eroa minun omani ja sinun omasi välillä, vaan itse kunkin on vain se, minkä hän voi saada, ja niin kauan, kuin hän voi sen pitää.” (L, XIII, 13. s. 125.) Ja koska kysymys omistuksesta on aina varhaismodernissa politiikan ja talouden teoriassa sidottu ihmisyksilöön, seuraa oikeuden ja lain puutteesta myös se, että "jokaisella on oikeus kaikkeen, jopa toisen ruumiiseen." (L, XIV, 4. s. 127.)

On siis selvää, että luonnontila on Hobbesille järjestäytyneen yhteiskunnan vastakohta. Järjestyksen luonnontilaan voisi puolestaan tuoda oikeusjärjestelmä, joka takaa yksilölle omistusoikeuden hänen omalla työllään hankkimiin hyödykkeisiin. Ilman yksityisomistuksen turvaavaa järjestelmää ihmisten ei ole järkevää yrittää, rakentaa, kouluttautua tai sivistyä. Luonnontilassa kaikki työ on hyödytöntä. Ilman tulevaisuushorisonttia, jonka suvereenin vallan (sovereign power) perustaminen yhteiskuntaan luo - siis ilman rauhaa, turvallisuutta ja keskinäistä luottamusta - ei ole myöskään työtä sanan varsinaisessa merkityksessä. Ilman yksityisomistusta ei ole myöskään yhteistyötä, jota vaaditaan suurten, ihmisyhteisön rakentamien hankkeiden toteuttamiseen. Ainoastaan turvattu yksityisomistus luo motiivin toimia toisten ihmisten kanssa, tehdä työtä ja yrittää.

Luonnontilassa suurimpana esteenä taloudelliselle toiminnalle on pelko oman työn kannattamattomuudesta. Pohjimmiltaan tämä pelko on toisten ihmisten pelkoa. Niin kauan kuin ihmiset pelkäävät, ovat epävarmoja ja huolestuneita he eivät kykene toimimaan rationaalisesti tai taloudellisesti. Kaikenlaiset mimeettiset liikkeet, kuten väkijoukossa leviävät huhut, juorut ja epäluulot saavat ihmiset tekemään harkitsemattomia, lyhyen aikavälin ratkaisuja. Ihmiset siis toimivat väkijoukossa täysin holtittomasti, mikä ei 
voi olla pitkäjänteisen taloudellisen toiminnan perusta. Toisaalta ihmiset myös eristäytyvät ja yksinäistyvät, mikä ei sekään edesauta taloudellista toimintaa.

Pelko on kuitenkin tarpeellinen ja välttämätön tekijä, jotta toimiva yhteiskunta voidaan rakentaa. Henkilökohtainen, väkivaltaisen kuoleman pelko ja toisaalta pelko oman työn hyödyttömyydestä ovat ihmisen suurimpia huolia. Niin kauan kuin nämä pelot vallitsevat, ihmiset eivät voi nousta korkeammalle, yhteisöllisen elämän tasolle. Luonnontilasta ihmisiä ajaa yhteiskuntaan nimenomaan keskinäinen pelko, sekä toisaalta mukavuuden halu. (L, XI, 5.) Tämän lisäksi rauhaan eli suvereenin vallan alaisuuteen houkuttelee "sellaisten asioiden haluaminen jotka ovat kunnollista elämää varten välttämättömät ja toivo saavuttaa niitä omalla yritteliäisyydellä” (L, XIII, 14. s. 125). Vasta valtiossa on mahdollista todella tehdä työtä ja harjoittaa vaihdantaa - ja näin myös vaurastua ja rikastua. Tarkastelen seuraavaksi miltä taloudellinen toiminta näyttää Hobbesin kaavailemassa valtiossa ja millaisen roolin pelko siinä saa.

\section{Valtio ja pelon taloustiede}

\section{Pelon logiikan muutos}

Luonnontilassa vallitseva ihmisten keskinäinen pelko ajaa ihmiset solmimaan yhteiskuntasopimuksen. Hobbesin mielenfilosofian mukaan pelosta tehdyt teot ovat tahdottuja ja siksi myös pelosta tehdyt sopimukset ovat sitovia. (L, VI, 54.) Pelko on motivaatio, joka pakottaa ihmisen harkintaan (deliberation). Harkinta on rationaalinen laskelma, jossa asian huonot ja hyvät puolet punnitaan. Harkinnan prosessia seuraava viimeinen johtopäätös on joko halu tai vastenmielisyys, joka määrittää toimintaan ryhtymisen. Tätä harkintaprosessin viimeistä halua Hobbes kutsuu tahdoksi (will) ja se on yhteiskunnan perustamisen kannalta olennainen asia. Motiivi yhteiskunnan perustamiselle on pelko, mutta pelosta huolimatta yhteiskuntasopimuksen solmiminen tapahtuu vapaasta tahdosta. (L, VI, 49-57.)

Hobbes korostaa De Civessä, että yhtäkään suurta yhteiskuntaa ei ole rakennettu minkään muun kuin pelon varaan $(D C, I, 2)$. Tämä ei kuitenkaan ensisijaisesti tarkoita yhteiskuntien hallitsemista pelolla, vaan nimenomaan 
ihmisten motiivia yhteiskunnan perustamiselle. Pelko oman elämän päättymisestä ja elossa säilymiseen tarvittavien resurssien menetyksestä pakottaa ihmiset hyväksymään heidän absoluuttista vapauttaan ja egoistista oman edun tavoittelua rajoittavan yhteisen vallan.

Suvereniteetti (sovereign power) on ihmisten yhteiskuntasopimuksella luoma valta, joka koskee jokaista ja kaikkia yhtäläisesti. Suvereniteetti on myös oikeusjärjestelmän perusta: suvereeni, siis suvereenin vallan (suvereniteetin) edustaja luo yhteiset lait, joita yhteiskunnassa tulee noudattaa. Olennaista on, että yhteiskunnassa tai valtiossa kansalaisten ei tarvitse pelätä toisiaan. Jokaisen kansalaisen suhde toiseen ihmiseen on välittynyt: jokaisen ihmissuhteen ja jopa ihmisen sisäisen itsesuhteen välittäjänä toimii suvereeni, siis lain ja järjestyksen määrittelijä ja ylläpitäjä. Eräällä tapaa vasta yhteiskunnassa ihminen voi olla toisista ihmisistä riippumaton yksilö. Ainoa vaadittava suhde on lojaalinen suhde valtioon.

Poistuuko pelko valtiosta sitten kokonaan? Ei, sillä ihmisluonnolle lajityypillisiä tunteita ei voida koskaan poistaa. Valtiossa ihmiset eivät kuitenkaan enää pelkää toisiaan, sillä toimiva oikeusvaltio kykenee takaamaan, että ihmiset eivät turvaudu oman käden oikeuteen ja jos näin tapahtuu, suvereeni kykenee rankaisemaan syyllisiä.

Nyt pelon kohteeksi muodostuu keskinäisen pelon (mutual fear) sijasta suvereeni (sovereign), siis koko monimutkainen aistihavainnon kohde nimeltä valtio. Valtio rajoittaa jokaisen yksilön toimintaa. Valtion tehtävänä on ehkäistä epäluuloa ja epäluottamusta, sekä niistä juontuvaa taloudellista tehottomuutta ja toimettomuutta. Siksi valtiokoneisto voi pakottaa ihmiset toteuttamaan sen, minkä he ovat yhteiskuntasopimuksessa solmineet.

Yhteiskuntasopimuksen tärkein periaate on, että kukaan ihminen ei asetu toisen liikkeen tielle - ei fyysisesti eikä metaforisesti. Luonnontilassa yksilöiden absoluuttisen vapaa liike aiheuttaa tungoksen, väen paljouden, jonka seurauksena kukaan ei voi toteuttaa tavoitteitaan. Valtiossa yksilöt sen sijaan liukuvat sulavasti toistensa ohi. (L, XVII, 3-4.) Toimivaa yhteiskuntaa voi verrata hyvin järjestettyyn liikenteeseen. Toisin sanoen yksilön liikkeellä ja toiminnalla täytyy olla jotain merkitystä ja tuo merkitys voi syntyä vain jos yksilö jaksaa tehdä töitä ja yrittää. Valtiossa ihmiset ovat siis mahdollisimman vapaita tekemään ja yrittämään sitä minkä he katsovat tärkeäksi. Tämä tapahtuu yleisen lainsäädännön puitteissa, mutta periaatteessa Hobbes ei kiellä mitään tiettyä toimintaa tai yritteliäisyyden muotoa. 
Ainoastaan toisten omistuksen ryöstäminen on kiellettyä.

Ennen kuin siirryn tarkastelemaan lähemmin valtiossa tapahtuvaa työtä, tuotantoa ja omistusta, on hyvä vielä pohtia lyhyesti valtion ja pelon yhteyttä yleisemmällä tasolla. Hobbesin sanoma on hyvin yksinkertainen. Elettäessä valtiossa ei ole mitään muuta pelättävää, kuin suvereniteetti ja suvereeni. Suvereeni on yhtä aikaa konkreettinen aistihavainnon kohde, abstrakti laillisuusperiaate sekä metafyysinen käsite. Aistihavainnon kohteena suvereniteetti ei koskaan ilmene suoraan. Valtio on kansalaisten yhteisvoiman (absoluuttisen vallan) representaation väline ja ilmetäkseen se tarvitsee edustusta. Suvereeni on suvereniteetin periaatteen, siis absoluuttisen ja jakamattoman voiman ilmentymä, julkinen persoona. (L, XVI-XVII.)

Hobbesin mukaan suvereniteettiä voi laillisesti edustaa demokraattinen hallitus, aristokraatinen kokous tai monarkia. Monarkia on näistä paras, sillä monarkiassa abstrakti suvereniteetin periaate ei ole suorassa ristiriidassa sen edustajan kanssa. Yhteiskuntasopimuksella luotu keinotekoinen henkilö (artificial person) on ykseys ja jos myös sen edustaja on yksi ihminen, monarkki, ilmenee poliittinen valta valtiossa kaikkein luonnollisimmalla tavalla. (L, XIX.)

Mutta, yhteiskunnan hallinto ei perustu vain yhden henkilön päätöksiin. Suvereenin apuna on suuri joukko virkamiehiä, neuvonantajia, oikeuslaitos ja tietysti myös armeija. Valtio ilmenee myös lakitekstissä, sillä kaikki lait ovat aina suvereenin säätämiä. Siksi abstrakti laillisuusperiaate ja käytännöllinen oikeus toimivat yhdessä. Toisin sanoen, siellä missä on kysymys oikeudesta, on aina kysymys valtiosta ja valtion käskyvallasta. (L, XXIII; XXV; XXVI.)

Eläessään yhteiskunnassa ihmiset havaitsevat suvereniteetin toiminnan, siis ymmärtävät elävänsä ja osallistuvansa valtion elämään erilaisten valtionhallinnon asioiden yhteydessä. Hobbes korostaa myös syvällisempää, arkipäiväiseen havainto- ja merkkivirtaan ja sen tulkintaan liittyvää valtion läsnäoloa. Todella toimivassa valtiossa ihmiset eivät kanna mukanaan lakikirjaa, vaan ovat sisäistäneet oikeutensa ja velvollisuutensa rippikouluun verrattavan koulutusjärjestelmän kautta. (L, XXX, 10-15.)

Sisäistetyt säädökset tulevat esille ihmisten käyttäytymisessä ja tapakoodistossa. Vaikka Hobbes ei ole moralisti, hän kuitenkin korostaa sitä kuinka voimme havaita toisten ihmisten käytöksestä yleviä ja vähemmän yleviä periaatteita, ja kuinka voimme tulkita toisten eleitä ja jopa ilmeitä eri 
tavoin. Ihmisten tunteet kertovat heidän joustavuudestaan ja sopivuudestaan yhteiskuntaan. Äärimmäisiä tunteita ilmaisevat yksilöt myös tartuttavat äärimmäisiä tunteita toisiin ihmisiin. Siksi on valtion intressin mukaista, että ihmisten keskinäinen toiminta ja jokapäiväinen käytös perustuvat hyviin tapoihin ja maltillisuuteen. Kaikki äärimmäiset liikkeet ovat vaarallisia ja suvereeni myös tarkkailee kaikkia suuria tunteita aiheuttavia tapahtumia.

Tunteet ja niiden ilmaisut ovat siis suvereenille eräänlainen ilmapuntari tai mittari, joka kertoo yhteiskunnan tilasta ja siellä vallitsevasta resistanssista. Koska tunteet ovat aina reaktiota johonkin, kertovat esimerkiksi verojen korostuksesta aiheutuvat tunteet paljon siitä, millaisella mielialalla alamaiset ovat. Voimakkaat reaktiot verojen korotukseen voivat aiheuttaa muutoksia valtionhallinnon suunnitelmiin, sillä liian suureksi kasvava vastarinta ei koskaan ole suvereenin edun mukaista, vaikka suvereenilla onkin lopulta keino pakottaa ihmiset tahtoonsa väkivallan monopolin avulla.

Mitä ihmiset siis pelkäävät valtiossa? He pelkäävät ensiksikin suvereniteetin periaatetta, jota Hobbes nimittää kuolevaiseksi jumalaksi tai Leviathaniksi. Tämä pelko on, kuten edellä on todettu, rationaalista. Se muistuttaa uskonnollista pelkoa, jonka Hobbes ymmärtää näkymättömän ja selittämättömän peloksi, mutta koska valtion rakentumisen ja sen toiminnan syyt ovat tiedossa, on valtio ymmärrettävä ja hyväksyttävä pelon kohde. Valtiota voidaan pelätä abstraktina periaatteena myös erilaisten aistihavainnon antamien syiden vuoksi.

Toiseksi, valtiossa jokaisen kansalaisen tulisi pelätä myös itseänsä, sillä jokaisessa ihmisessä on luonnollinen ja keinotekoinen puoli, siis "luonnontilainen" (man) ja "sivilisoitunut" (citizen) puoli. Valtiossa eläminen vaatii itsekontrollia, mikä ei ole erilaisin haluin, toivein ja peloin varustetulle ihmisolennolle itsestään selvää. Jokaisessa ihmisessä on piirteitä, jotka altistavat hänet valtion vastaisiksi tulkittaviin tekoihin. Siksi Leviathan on, Raamatun Jobin kirjaa mukaillen "ylpeyden kuningas" (L, XXVIII, 27). Hobbes kritisoi kaikkea yksilöllistä mainetta, kunniaa ja suosiota tavoittelevaa toimintaa. (L, XXVII, 13.) Kansalaisten harjoittama, säädyllisyyteen ja maltillisuuteen tähtäävä itsekontrolli on valtiossa olennainen hallintamuoto.

Edellisistä seuraten, kolmantena pelon kohteena on luonnontila ja kaikki luonnontilaan mahdollisesti johtava toiminta. Itsekontrollin murentuessa ja valtion hallinnon epäonnistuessa kaikkia kansalaisia uhkaa suistuminen luonnontilaan. Luonnontila ei siis ole oikeastaan taakse jätetty ihmisen 
esihistoriallinen vaihe, vaan pikemminkin dystopia, joka uhkaa ihmisiä jatkuvasti ja siksi rajoittaa heidän toimintaansa valtiossa. Itsekontrollin puutteen seurauksena ihminen voi joutua vankeuteen tai hänet voidaan tappaa. Hobbesin mukaan tämä on kuitenkin pieni pelko verrattuna siihen, että koko oikeusjärjestelmä ja valtio romahtavat, jolloin ihminen ei ole oikeusjärjestelmän vaan toisten ihmisten armoilla. (L, XXIX.)

Hobbes vetoaa luonnontilan pelkoon, minkä seurauksena hän hyökkää kaikkia väkijoukon (multitude) logiikalla toimivia ihmisryhmiä kohtaan. Valtiossa kansalainen elää aina yksilöllisessä suhteessa valtioon, eikä hänen tule olla erilaisten lahkojen, puolueiden tai muiden vastaavien jäsen kuin toissijaisesti, valtion organisaation pyrkimysten mukaisesti. Ihmisten itsenäinen organisoituminen valtiossa on aina vaarallista, sillä se voi johtaa väkijoukon logiikan leviämiseen, keskinäiseen riitaan ja konfliktiin sekä lopulta valtion suvereniteetin kyseenalaistamiseen, mikä edistää luonnontilan syntymistä. ( $L$, XXIX.) Valtiossa ihminen tekee siis työtä, koska hän pelkää suvereenia, kuten Labiano $(2000,138)$ huomauttaa. On kuitenkin tärkeää korostaa, että suvereenin pelko on Hobbesin mukaan aina rationaalisempaa kuin alistuminen väkijoukon tuottamalle järjettömälle pelolle.

Työ, tuotanto ja valtion elinvoimat

Yhteiskunnan RAVITSEMUKSEN muodostaa elämää edistävien materiaalinen runsaus ja jakelu. Siihen kuuluu, että niitä tuotetaan tai valmistetaan ja tuotettuina toimitetaan soveliaalla tavalla yleiseen käyttöön (public use). Luonto rajoittaa materian runsauden niihin tavaroihin (commodities), joita Jumala yleensä joko antaa ilmaiseksi tai myy työtä vastaan ihmiskunnalle yhteisen äitimme rinnoista - maasta ja merestä. (L, XXIV, 1-2. s. 217.)

Työ yhdistettynä luonnon raaka-aineisiin on ihmiselämän perusta. Ilman työtä ei ole hyvinvointia, mutta itse asiassa ei myöskään elämää. Kaiken taloudellisen toiminnan perusta on yksilön tekemä työ. Tekemällä työtä ihminen erottautuu muusta luonnosta ja rakentaa maailmaa, jossa näkyy jälki ihmisen toiminnasta. Hobbes ymmärtää työn hyvin modernilla tavalla ilmoittaessaan, että itse asiassa työ on "tavara (commodity), joka on vaihdettavissa johonkin hyötyyn kuten mikä tahansa muu..." (L XXIV, 4. s. 217). 
Työ ei ole siis ainoastaan yksilöllisen hengissä säilymisen ehto, vaan myös yhteiskunnassa tapahtuvan taloudellisen vaihdannan perusta. Vain hyödykemuotoisen (commodity), vaihdettavan työn kautta ihmiset pystyvät hankkimaan ne asiat, joita hyvä elämä vaatii.

Työ ei kuitenkaan ole itsestäänselvyys. Hobbesin mukaan ihmisen on taisteltava kyetäkseen tekemään töitä. ${ }^{19}$ Köyhyyden voittaminen ja elämälle tarpeellisten hyödykkeiden hankkiminen vaatii ihmisiltä valmiutta taistella sen vuoksi, että he saavat tehdä töitä. Tämä koskee erityisesti niitä, joilla ei ole perintöjä ja jotka eivät elä vauraudessa. Köyhien ei siis tule valittaa valtion keräämistä veroista, vaan pikemminkin muistaa, että juuri valtio takaa heille mahdollisuuden työhön. Valtio nimittäin pitelee kädessään miekkaa, jolla työn ja tuotannon aluetta kokonaisuudessaan puolustetaan. (DC, XI, 9-10.)

Yksi Hobbesin kaavaileman suvereenin suurimpia pelkoja on pelko joutilaasta väestöstä, koska joutilaisuus tuottaa aina köyhyyttä - ja päinvastoin. Valtion tehtävänä on huolehtia siitä, että jokaisella kansalaisella on mielekästä työtä, sillä pitkitetty joutilaisuus tuottaa mitä todennäköisimmin kapinoita. ${ }^{20}$ Hobbes ymmärtää työttömien tilanteen. Jos ihmisellä ei ole varaa hankkia elantoaan tekemällä työtä, hän näkee syyn heikkoon tilanteeseensa aina toisissa ja valtaa pitävissä. Vaikka Hobbes ymmärtää vallankumouksellisuuteen johtavat syyt, on tällainen toiminta kuitenkin valtion kannalta huolestuttavaa, koska Hobbes ei uskonut, että kapinoinnista seuraisi uusi, parempi yhteiskunta. Päinvastoin, vallankumous uhkaa hajottaa yhteiskunnan ja palauttaa ihmiset takaisin luonnontilaan. Sen vuoksi joutilas väestö on aina työllistettävä, mutta jos tämä ei ole mahdollista, on joutilas väestö lähetettävä kolonioihin. ( $L, \mathrm{XXX}, 19$.

Hobbeslaisen sisäpoliittisen väestö- ja talouspolitiikan taustalla on pelko joutilaista väkijoukoista, jotka on mahdollista houkutella valtionvastaiseen toimintaan lähes millä tahansa populistisilla argumenteilla, jotka lupaavat työtä ja hyvinvointia. Suurimmat uhat valtion hajoamiselle tulevat aina valtion sisältä, eivät valtion ulkopuolelta. Yhteiskunnallisesti katsottuna työ on ihmisten tärkein kontrolliväline. Se on ihmisten luonnollisen liikkeen ohjaamista tuottavaan, järkevään ja valtiota rakentavaan toimintaan.

Työ ylläpitää kuria ja kohtuullisuutta, tarjoaa ihmisille mahdollisuuden vaurastua ja elää hyvin. Mutta työllä on myös laajempia kansantaloudellisia vaikutuksia. Hobbesin yksi kuuluisimmista lauseista (Ciceron maksiimia 
kierrättävä periaate) on Salus populi suprema lex (L, johdanto). Lause on usein käännetty yksinkertaistaen muotoon "Kansan turvallisuus on korkein laki”. Lauseen merkitys ei kuitenkaan liity vain suvereenin ensimmäiseen tehtävään, siis miekan avulla tapahtuvaan valtion ja sen kansalaisten puolustamiseen. Sanan salus toisena, yhtä tärkeänä merkityksenä on hyvinvointi. Hobbes viittaakin lauseella niin sotilaalliseen turvallisuuteen kuin työnteolla saavutettavaan hyvinvointiin. Valtion tehtävänä on huolehtia näistä molemmista.

Valtion suojeluksessa tehtävä työ ja tuotanto, sekä siitä seuraava kansalaisten lisääntyminen, voimistuminen ja yleisten resurssien runsaus lisäävät myös valtion itsensä elinvoimaa. Vaikka vertaus on monilla tavoilla ontuva, Hobbes rinnastaa valtion usein yksilöön. Kansalaiset ovat valtion materia ja heidän liikkeensä ovat valtion liikkeitä. Köyhä, joutilas ja työtön kansa tarkoittaa siksi myös heikkoa valtiota. Epäilemättä Hobbesin talouspoliittisesta ajattelusta on löydettävissä biovaltaan liittyviä ulottuvuuksia, sillä valtion elinvoiman huolehtiminen ja sen lisääminen johtaa väistämättä valtionhallintoon, joka on kiinnostunut väestönsä elämästä ja kyvykkyydestä. ${ }^{21}$ Toisin sanottuna, suvereenin valta ei ole Hobbesilla vain valtaa tappaa kansalainen tai jättää hänet kuolemaan, vaan tämän lisäksi Hobbes on kiinnostunut siitä, kuinka kansalaisista saadaan tehtyä tuottavia, ahkeria ja tunnollisia työläisiä. Heikkojen ihmisten valtio on maailmanpoliittisesti liian helppo saalis valloittajille, ajattelee Hobbes.

\section{Valtio ja yksityinen rikkaus}

Hobbeslaisen valtion suurin pelko on köyhyys, sillä se aiheuttaa joutilaisuutta ja johtaa ennen pitkää yhteiskunnan luonnontilaan suistaviin kapinoihin. Mutta myös varakkaiden ihmisten yhteenliittymät aiheuttavat ongelmia. (L, XXIX, 19.) Hobbesin aikakaudella Pohjois-Eurooppa eli myöhäisrenessanssia. Alankomaat kävi raskaan sodan irrottautuakseen katolisen Espanjan maailmanmahdista. Alankomaat nousi nopeasti köyhästä pohjoisesta maaseutualueesta maailman johtavaksi kolonialistiseksi valtioksi, jolla oli suuri ja nopea kauppalaivasto. Hollannin politiikka oli poikkeuksellista suhteessa muihin Pohjois-Euroopan valtioihin. He sallivat lähes täydellisen vapaakaupan ja keräsivät vain minimaalisia veroja kaupankäynnistä. Toisin sanoen, Hollanti oli yksi 1600-luvun ensimmäisiä todella kapitalistisia 
valtioita.

Hobbes vastusti Hollanin harjoittamaa politiikkaa ja näki, että vuonna 1652 alkaneen Englannin ja Alankomaiden välisen meriherruuteen ja kauppamonopoleihin liittyneen sodan aloitti Alankomaat (B, 175-180.) Hänen mukaansa valtiolla tuli olla ehdoton oikeus veronkeräykseen ja kaikesta kaupankäynnistä tuli maksaa verot ja tullit. Verot tuli maksaa juuri siitä syystä, että vain valtio pystyy suojelemaan voimallaan kaupankäyntiä ( $L$, XXIX, 18.) Hobbes ei siis kannattanut rajoittamatonta vapaakauppaa. Syy tähän löytyy peloista, jotka liittyvät valtion turvallisuuteen ja hyvinvointiin.

Suuret kauppakaupungit ja vaurastuneet kauppiasseurat käyttäytyivät Hobbesin mukaan kapinallisella tavalla varustaessaan omia armeijoitaan. Hobbesin mukaan valtiossa tuli olla vain yksi armeija, jota rahoitettiin kansalaisilta kerätyin veroin. Yksityisarmeijat johtavat keskinäiseen kilpailuun, kapinointiin ja lopulta luonnontilaan. (L, XXIX, 21.)

Hobbes halusi rajoittaa yksityisomistusta ja kauppakomppanioiden toimintaa, sillä hän näki niiden lisäävän yhteiskunnallista sekasortoa. Hobbes ei myöskään hyväksynyt kauppamonopoleja, vaikka hän ymmärsi hyvin niiden toiminnan periaatteet ja syyt. Hobbesin mukaan korporaatioiden eli kauppiaiden yhteenliittymien lopullisena päämääränä on kasvattaa voitot mahdollisimman suuriksi. Tämä ei kuitenkaan ole hyväksi kansalle, sillä annettaessa korporaatioille täysin vapaat kädet kaksoismonopolien muodossa (tuonti- ja vientimonopolit), ne eivät myy tuotteita halvimpaan, vaan kalleimpaan mahdolliseen hintaan. Tällaiset korporaatiot eivät tavoittele yhteistä, vaan yksityistä etua. (L, XXII, 18-21.)

Hobbesin mukaan yksityisiä korporaatioita ja muita yhteenliittymiä ei tule koskaan päästää kasvamaan liian suuriksi. Tästä Hobbesilla oli konkreettisia kokemuksia ja selvää näyttöä Englannin sisällissodasta. Englannin sisällissota käytiin nopeasti rikastuneen ja kuninkaan valtaan kyllästyneen kauppaporvariston sekä toisaalta perinteisemmän kuningasmielisen maa-aristokratian välillä. Teoria absoluuttisesta suvereenista taistelee nimenomaan erilaisia nousevan porvariston esittämiä vaatimuksia ja sen poliittista organisoitumista ja aseistautumista vastaan.

Vaikka Hobbes kritisoi köyhï joutilaisuudesta ja siitä, että he syyttävät valtiota huonosta osastaan, kohdistuvat varsinaiset syytökset valtion vallan kyseenalaistamisesta aina kauppaporvaristoon. Kulminaatiopisteenä ovat verot, joita porvaristo ei haluaisi maksaa. Ilman verotuloja ja vaurautta 
valtio ei kykene hoitamaan tehtäviään eli huolehtimaan kansan turvallisuudesta ja hyvinvoinnista. (L, XXIX, 18.)

Hobbes ei myöskään usko, että valtion hyvinvointi voisi muodostua "automaattisesti" yksilöiden pyrkiessä toteuttamaan omat intressinsä ja halunsa. Hobbesin mukaan intressejä ja haluja, siis ihmisten liikettä, tulee muokata ja ohjata rationaalisesti siten, että ne parhaiten toteuttavat niin yksilön kuin valtionkin tavoittelemat asiantilat. Suuromistajien ja suurpääoman kritiikin vuoksi Hobbesin talouspolitiikka on siis erän̈laista säädeltyä ja valtiojohtoista pienyrittäjyyttä.

Julkisella vallalla ei kuitenkaan ole velvollisuutta työllistää, saati omistaa omaisuutta. Valtio ei omista maata (joka on omistuksen perusta) eikä sillä ole jatkuvia, varmoja tulonlähteitä. Valtio kerää varantonsa aina veroilla ihmisiltä tarpeen mukaan. Julkinen omaisuus olisi alttiina omaa etua tavoittelevalle ihmisluonnolle. Näin esimerkiksi ahne hallitsija voisi käyttää julkista omistusta värrin tai sitoa julkiset varat pitkään ja kalliiseen sotaan. Kaikki tällainen asettaa yhteiskunnan riskialttiiseen asemaan. (L, XXIV, 8.)

Hobbesin mukaan yhteinen omistus onkin mahdottomuus. Luonnontilassa ei ole olemassa omistusta eikä omistusoikeutta. Luonnontilassa kaikki asiat ovat yhteisiä (common), mikä ei kuitenkaan tarkoita, että luonnontilassa vallitsisi kommunismi, siis systemaattisesti organisoitu yhteisomistus. Pikemminkin luonnontilaa leimaa sekavuus ja organisoimattomuus, mistä johtuen omistusta ei ole olemassa missään muodossa. Kuka tahansa voi käyttää mitä tahansa asiaa, ihmistä tai ajatusta. Omistus sen sijaan on aina pysyvää, henkilöön kiinnitettyä ja tässä mielessä abstraktia.

Omistusoikeus on Hobbesille hankala ja monimutkainen kysymys. Hän näkee, että yksityisomistus on valtion perusta, mutta samaan aikaan korostaa, että lopulta vain ja ainoastaan valtio määrittelee omistusoikeuden ja siten myös säätelee omistuksen märää. Leviathanissa hän huomauttaa selväsanaisesti, että "...omistus [...] on kaikissa yhteiskunnissa suvereenin vallan asia." ( $L$, XXIV, 5. s. 218). Valtio luo siis mahdollisuuden omistukseen tuottamalla turvallisuuden ja varmuuden luonnontilan turvattomuuden ja epävarmuuden tilalle. Ciceroa seuraten Hobbes siis esittää, että omistus on aina lainsäädännön tuottama asia. Yksityisomaisuutta ei myöskään saa koskaan päästää kasvamaan niin suureksi, että se uhkaisi jollain tavalla valtiota.

Koska omistus on aina arbitraarista eli lakia säätävän elimen 
oikeuskäsityksen mukaista, ovat myös omistuksesta johtuvat erot suvereenin säätämiä tai vähintäänkin sen sallimia. Yhteiskunnallisen järjestyksen takaavat hierarkiat perustuvat yhteiskunnalliseen eriarvoisuuteen. Kaikki toiminta, jossa yhteiskunnan asettamasta eriarvoisuudesta ja hierarkioista pyritään eroon, voidaan tulkita kapinoinniksi, joka uhkaa romahduttaa valtion.

Vaikka hobbeslainen valtio mahdollistaa rikkaan luokan muodostumisen, Hobbes ei kuitenkaan suosi suurten omaisuuksien tai "aarteiden" kasaamista. Leviathanissa hän kehottaa ihmisiä jakamaan kaiken sen mikä on heille ylimääräistä. Tämä toteutuu erilaisten suvereenin valvomien vaihtojärjestelmien kautta, joiden tarkoituksena on valvoa vaihtamisen sääntöjä siis ostamista, myymistä, lainaksi ottamista ja antamista, vuokraamista ja niin edelleen. Hobbesin mukaan niin ylimääräisen omaisuuden kuin esimerkiksi rahan tulee kiertää yhteiskunnassa, sillä tästä muodostuu yhteiskunnan verenkierto, joka oikein toimiessaan ravitsee sen kaikkia osia. (L, XXIV.)

Luonnontilaisesta valtavan tavaramäärän omistamisesta ja vartioinnista tulisi siirtyä rahaperustaiseen järjestelmään, jossa ihminen voi käytännössä ostaa haluamansa ja tarvitsemansa asiat mistä tahansa, milloin tahansa ja näin ravita yhteiskunnan eri osia. Yksityisen varallisuuden tarkoituksena on liikkua ja kiertää yhteiskunnassa. Taloudellinen pysähtyneisyys, toisin sanottuna aarteiden kasaminen johtaa tilanteeseen, jossa yhteiskunnan elinvoimat heikkenevät ja sitä uhkaa jälleen luonnontila. Jos rikkaudella on jokin erityinen rooli Hobbesin kaavailemassa valtiossa, on sen tärkein tehtävä huolehtia jatkuvasta investoinnista sitä kaipaaville aloille.

\section{Lopuksi}

Olen tarkastellut Hobbesin talouspoliittisten näkemysten ja pelon suhdetta Hobbesin filosofialle keskeisen järjestyksen ongelman yhteydessä. Tarkastelun perusteella voidaan todeta, että talous - siis työn, tuotannon, omistuksen ja markkinoiden organisoitu kokonaisuus - on Hobbesin politiikan teorian keskeinen osa.

Luonnontilan ongelma kiteytyy työn ja omistuksen kysymyksiin. Luonnontilassa ihminen tekee työtä, mutta työn päämääränä ei ole mikään muu 
kuin oman hengissä säilymisen turvaaminen. Ihmisten tasa-arvoisuudesta johtuen mikään ei kuitenkaan voi turvata hengissä pysymistä luonnontilassa. Vaikka jotkut ihmiset saattavatkin koota suuria määriä hyödykkeitä ja resursseja haltuunsa, eivät he varsinaisesti omista mitään. Omistus puolestaan on vakaan ja rauhallisen yhteiskunnan perusta, sillä ilman mahdollisuutta turvalliseen omistukseen, ihmisillä ei ole motivaatiota työntekoon tai yritteliäisyyteen. Motivaation ja yritteliäisyyden puutteen vuoksi luonnontila on metafora ihmisen köyhyydelle ja laiskuudelle, joka puolestaan ruokkii nopeita, lyhyen tähtäimen tavoitteita, moraalittomuutta ja holtittomuutta.

Luonnontilassa vallitsevan epäluottamuksen takia sieltä puuttuvat myös talouden toiminnalle olennainen vaihtaminen ja markkinat. Ilman luottamusta yksityisen työn hedelmät kasautuvat yksilöille (joskin tämän "omaisuuden" voi menettää milloin tahansa), mutta ne eivät lähde yhteiskunnalliseen kiertoon. Ilman vaihdantaa ja markkinoita yksityisten ihmisten vauraus, taidot ja työkyky eivät pääse palvelemaan ihmisyhteisöä. Siksi Hobbes ei kannata yksityisten "aarteiden" kasaamista ja yksityishenkilöiden tai julkisten persoonien tarpeen ylittävää vaurastumista. Kaikki ylimääräinen on investoitava ja laitettava kiertoon.

Hobbesin talouspoliittinen malli suosii yritteliäitä kansalaisia, ahkeria protestanttisia puurtajia, jotka ovat valmiita työskentelemään ja tuottamaan enemmän kuin heidän oma tarpeensa vaatii. Tällainen uutteruus tuottaa markkinoille hyödykkeitä, jotka parantavat puolestaan kaikkien ihmisten elämää. Hobbesin yhteiskunta on työtä tekevien yhteiskunta, jossa yksilöiden työ vaurastuttaa ja voimistaa koko yhteiskuntaa.

Jos Hobbesia siis haluttaisiin nimittää kapitalismin isähahmoksi, olisi hänet nähtävä nimenomaan eräänlaisen pienyrittäjyyteen perustuvan valtiokapitalismin puolestapuhujana. Hobbes tuntee vastenmielisyyttä räyhäkkääseen kauppaporvaristoon ja yleisesti aikakautensa suurpääoman omistajia kohtaan - vaikka viettikin koko elämänsä yhden Englannin rikkaimman aristokraattisuvun palveluksessa. ${ }^{22}$

Talouden on oltava Hobbesin mukaan aina alisteista politiikalle. Poliittisen johdon tehtävänä on ohjata ja säädellä taloudellista toimintaa. Tässä mielessä Hobbes ei ole liberalisti, eikä hän missään nimessä kannattanut minkäänlaista laissez-faire politiikkaa. Pikemminkin hän kannattaa säädeltyä talousjärjestelmää, jonka tarkoituksena on kansan kokonaisvaurauden lisääminen. 
Siksi, vaikka talouden ja politiikan alueet ovat Hobbesille yhtäläiset ja ne syntyvät yhtäaikaisesti yhteiskuntasopimuksen toteuttamisen kanssa, politiikka ohjaa aina taloutta ja talous on lopulta vain keino politiikan toteuttamiselle. Hobbesin mukaan politiikan tiede on perustaltaan geometriaa, jakamisen tiedettä. Yhteisesti tuotetun vaurauden oikeudenmukaisesta jakautumisesta päättää aina viimekädessä suvereeni.

Mikä rooli sitten pelolla on Hobbesin talouspoliittisessa ajattelussa? Ensiksikin, luonnontilassa vallitseva ihmisten keskinäinen pelko ruokkii epäluottamusta ja epävarmuutta. Näissä oloissa taloudellinen toiminta on Hobbesin mukaan mahdotonta. Keskinäisen pelon ja siitä aiheutuvan köyhyyden ja elämän yleisen epävarmuuden vuoksi ihmiset tahtovat perustaa valtion. Valtio rajoittaa ihmisten luonnonoikeutta ja absoluuttista vapautta tehdä mitä tahansa, ottaa mitä tahansa ja käyttää mitä tahansa jopa toisen ihmisen ruumista. Sen sijaan se mahdollistaa omistuksen, joka on aina rajoitettua ja säädeltyä, mutta kestävää valtion pysyvyyden rajoissa.

Valtiossa pelon logiikka muuttuu. Kansalaisilla ei ole syytä pelätä toisiaan, sillä suvereeni pitää huolen kansalaisten välisten suhteiden oikeudenmukaisuudesta. Sen sijaan pelon kohteena on nyt valtio. Kenellä tahansa työtä tekevällä, yritteliäällä ihmisellä on aito syy tuntea kunnioitusta valtiota kohtaan, joka kykenee voimallaan ottamaan omistuksen pois oikeutetusti. Tämä pelote saa aikaan kansalaisissa valtion tahdon mukaista työtä ja toimintaa. Toisin sanottuna, ihmiset työskentelevät, tuottavat, myyvät ja ostavat valtion asettamien säädöksien puitteissa. Lopullisena rajoitteena toimii rangaistusten pelko, joka pahimmillaan voi tarkoittaa oman hengen menettämistä.

Valtiossa taloudellista toimintaa vie eteenpäin myös luonnontilan pelko. Pelko vajoamisesta anarkiaan (joka tarkoittaa Hobbesin mukaan vallan puutetta), pitää ihmiset työssä ja toiminnassa. Ihmiset valitsevat mieluummin suvereenin tarjoaman järjestyksen ja yhteiskunnallisen hierarkian kuin luonnontilan, jossa ei ole mitään järjestystä eikä hierarkiaa. Valtiossa jokaisella on mahdollisuus omalla työllään nostaa yhteiskunnallista asemaansa, kuten Hobbesille itselle tapahtui koulutuksen kautta. Luonnontilassa kaikki on sen sijaan kiinni sattumasta, röyhkeydestä ja onnesta. Se ei tarjoa mitään kunniallisia tapoja menestykseen.

Mutta pelolla on tärkeä rooli myös kansalaisten ja valtionhallinnon välisessä suhteessa. Valtion hallinto nimittäin pelkää kaikkea kapinointia, 
vallankumouksellisuutta tai muuta vastaavaa liikehdintää. Suurimpana syynä kapinointiin Hobbes näkee joutilaan, köyhän ja tyytymättömän väestön syntymisen. Tällainen väestö on valmis hylkäämään yhteiskuntasopimuksen, sillä sen tärkein peruslupaus, lupaus turvallisesta omalla työllä vaurastumisesta ja omistamisesta on petetty. Vaikka Hobbesin kaikki keinot joutilaan ja köyhän väestön ongelman ratkaisemiseen eivät olekaan kestäviä (äärimmillään köyhät tulee lähettää kolonioihin, jossa he voivat viljellä maata ja tehdä työtä), hän ymmärtää hyvin työttömyyden mukanaan tuoman yhteiskunnallisen järjestyksen perusongelman. Pelko suistumisesta luonnontilaan koskettaa siis yhtälailla kansalaisia kuin suvereenia. Pelko sitoo hallitsijan ja hallitut yhteen, se saa aikaan vuoropuhelun, jossa molempien toimintaa ja roolia pohditaan. Toisin sanoen, vain ja ainoastaan pelko voi toteuttaa kehittyvän ja yhteistyölle perustuvan talouden. 


\section{Kirjallisuus}

Ahrensdorf, Peter J. 2000. The fear of death and the longing for immortality: Hobbes and Thucydides on human nature and the problem of anarchy. The American Politial Science Review, 94:4, 579-593.

Angoulvent, Anne-Laure. 1992. Hobbes ou la crise de l'État baroque. Paris: PUF.

Biondi, Darick. nd. Hobbes and Locke: A confused capitalist and his "counterpoint". http://www.wju.edu/academics/bus/iscm/dbiondi.pdf

Baumgold, Deborah. 2013. "Trust" in Hobbes's political thought. Political Theory, 41:6, 838-855.

Burger, Thomas. 1977. Talcott Parsons, the problem of order in society, and the program of an analytical sociology. American Journal of Sociology, 83:2, 320-339.

Ellis, Desmond P. 1971. The Hobbesian problem of order: a critical appraisal of the normative solution. American Sociological Review, 36:4, 692-703.

Esposito, Roberto. 2000. Communitas. Origine et destin de la communauté. Paris: PUF.

Esposito, Roberto. 2008. Bios: Biopolitics and philosophy. Minneapolis: University of Minnesota Press.

Foucault, Michel. 2007. Histoire de la sexualité I: La volonté de savoir. Paris: Tel. Gallimard.

Gert, Bernard. 1989. Hobbes's account of reason and the passions. Teoksessa Bertman ja Malherbe (toim.): Thomas Hobbes. De la métaphysique a la politique. Paris: J. Vrin.

Gert, Bernard. 1996. Hobbes's psychology. Teoksessa Tom Sorell (toim.): The Cambridge companion to Hobbes. Cambridge: Cambridge University Press, 157-174.

Hobbes, Thomas. 1990 [B]. Behemoth or The Long Parliament. Chigago: The University of Chicago Press. 
Hobbes, Thomas. 1839-1845 [DC]. De Cive in Thoma Hobbes Malmesburiensis opera philosophica qua Latine scripsit Omnia in unum corpus nunc primum collecta studio et labore Gulielmi Molesworth, vol. II. Faksimile edition. 1839-1845 painoksesta. London: British Library.

Hobbes, Thomas. 1998 [DC]. On the Citizen. Cambridge: Cambridge University Press.

Hobbes, Thomas. 2005 [EL]. Elements of Law in English Works of Thomas Hobbes of Malmesbury: Elibron Classics. 2005.

Hobbes, Thomas. 1998 [L]. Leviathan. Oxford: Oxford University Press. 1998.

Hobbes, Thomas. 1999 [L]. Leviathan. Suomentanut Tuomo Aho. Tampere: Vastapaino.

Hull, Gordon. 2009. Hobbes and The Making of Modern Political Thought. London and New York: Continuum.

Jakonen, Mikko. 2012. Kaaoksen ja järjestyksen filosofi Thomas Hobbes. Koikkalainen \& Korvela (toim.): Klassiset poliittiset ajattelijat. Tampere: Vastapaino, 203-242.

Jakonen, Mikko. 2013. Multitude in Motion. Re-Reading on Thomas Hobbes's Political Philosophy. Jyväskylä: Jyväskylän yliopisto. https://jyx.jyu.fi/dspace/ bitstream/handle/123456789/41204/978-951-39-5164-1_vaitos27042013. pdf? sequence $=1$

Kangas, Risto. 2006. Yhteiskunta. Helsinki: Tutkijaliitto.

Labiano, Jesus M. Zaratiegui. 2000. A reading of Hobbes' Leviathan with economists' glasses. International Journal of Social Economics, 27:2, 134-146.

Lemetti, Juhana. 2012. Historical Dictionary of Hobbes's Philosophy. Lanham, Toronto, Plymouth: Scarecrow Press.

Levy, Aaron. 1954. The Economic Views of Thomas Hobbes. Journal of the History of Ideas, 15:4, 589-595.

MacPherson, C.B. 1962. The Political Theory of Possessive Individualism: Hobbes to Locke. New York: Oxford University Press. 
MacPherson, C.B. 1987. Thomas Hobbes. Teoksessa The New Palgrave's Dictionary of Economics, 2. London: Macmillan, 663-664.

Marshall, James D. 1996. Foucault: Personal Autonomy and Education. Dortrecht: Kluwer Academic Publishers.

Marx, Karl. 2009. Hegelin oikeusfilosofian kritiikkiä. Jyväskylä: Sophi / Minerva.

Montchrestien, Antoine de. 1889. Traicté de l'Economie politique. Paris: Librarie Plon.

Pabst, Adrian. 2010. Modern Sovereignty in Question: Theology, Democracy and Capitalism. Modern Theology, 26:4, 570-602.

Parsons, Talcott. 1968. The Structure of Social Action. New York: The Free Press.

Pavlich, George. 2010. On the subject of sovereigns. Teoksessa Barbour ja Pavlich (toim.): After Sovereignty. London: Routledge, 22-36.

Sorell, Tom (toim.) 1996. The Cambridge companion to Hobbes. Cambridge: Cambridge University Press.

Sorell, Tom. 2011. Hobbes, public safety and political economy. Teoksessa Prokhovnik ja Slomp (toim.): International political theory after Hobbes. London: Palgrave.

Springborg, Patricia. 2007. The Cambridge companion to Hobbes's Leviathan. Cambridge: Cambridge University Press.

Taylor, Quentin. 2010. Thomas Hobbes, political economist - his changing historical fortunes. The Independent Review, 14:3, 415-433.

Thornton, Helen. 2005. State of nature or Eden? Thomas Hobbes and his contemporaries on the natural condition of human beings. New York: The University of Rochester Press.

Tricaud, Francois. 1988. Hobbes's conception of the state of nature from 1640 to 1651: evolution and ambiguities. Teoksessa G. A. J. Rogers ja Alan Ryan (toim.): Perspectives on Thomas Hobbes. Oxford: Clarendon Press.

Vinnicombe, Thea \& Staveley, Richard. 2002. John Locke, Thomas Hobbes and the development of political economy. International Journal of Social Economics, 
29:9, 690-705.

Wright, George. 1999. Hobbes and the economic trinity. British Journal for the History of Philosophy, 7:3, 397-428.

Zarka, Yves Charles. 1995. Hobbes et la pensée politique moderne. Paris: PUF.

\section{Viitteet}

I) Esimerkiksi Tom Sorellin toimittama Cambridge Companion to Hobbes (1996) tai Gabriella Springborgin toimittama Cambridge Companion to Hobbes's Leviathan (2007) ei sisällä taloutta koskevia artikkeleita. Myöskään vuodesta 1988 lähtien ilmestyneessä Hobbes Studies -lehdessä ei ole julkaistu yhtään taloutta käsittelevää artikkelia.

2) Hobbesin taloutta ja poliittista taloustiedettä käsitteleviä artikkeleita on julkaistu jonkin verran. Yksi varhaisista teksteistä on Aaron Levyn (Levy 1954) vuonna 1954 julkaisema "The economic views of Thomas Hobbes", joka summaa yhteen Hobbesin taloudellisia näkökantoja. Yves Charles Zarka kirjoitti vuonna 1995 julkaistussa Hobbes et la pensée politique moderne -kirjassa kattavan luvun Hobbesin omaisuuden käsitteen asemasta hänen poliittisessa filosofiassaan (Zarka 1995, 172-196.) Viime aikoina kiinnostus Hobbesin taloudelliseen ajatteluun on lisääntynyt jonkin verran, vaikka se onkin edelleen marginaalissa Hobbes -tutkimuksessa. 2010 julkaistu Quentin Taylorin (Taylor 2010) artikkeli "Thomas Hobbes, political economist - his changing historical fortunes" esittelee Hobbesin muuttuvaa asemaa poliittisen taloustieteen historiassa. Myös Jesus M. Zaratiegui Labianon artikkeli "A reading of Hobbes' Leviathan with economists' glasses" vuodelta 2000 käsittelee Hobbesin poliittista teoriaa talouden näkökulmasta. Tämän lisäksi Hobbesin ja modernin suvereniteetin teologista ja kapitalistista perustaa tarkastelee Adrian Pabstin "Modern sovereignty in question: Theology, democracy and capitalism" sekä George Wrightin artikkeli "Hobbes and the economic trinity". Myös Tom Sorell käsittelee Hobbesin poliittista taloustiedettä artikkelissaan "Hobbes, public safety and political economy" (Sorell 2011). On huomattava, että vaikka Hobbesin taloudellisia näkökulmia käsitellään jonkin verran Hobbes kirjallisuudessa, 
Hobbesin filosofiaa käsittelevät sanakirjat eivät esimerkiksi sisällä artikkeleita sanoilla labour, work, economy, markets tai industry (ks. esim. Lemetti 2012).

3) Macpherson 1962; Macpherson 1987.

4) Katso Vinnicombe \& Staveley 2002. Poikkeava kanta tästä, katso Biondi 2007.

5) On myös hyvä muistaa Karl Marxin tekemä ero poliittisen taloustieteen ja kansantaloustieteen välille. Hegelin oikeusfilosofian kritiikissä hän kirjoittaa seuraavasti: "Kun ongelma Ranskassa ja Englannissa kuuluu: poliittinen taloustiede eli yhteiskunnan herruus rikkauden yli, kuuluu se Saksassa: kansantaloustiede eli $y k s i-$ tyisomaisuuden herruus kansallisuuden yli." (Marx 2009, 86-87.)

6) Esimerkiksi Leviathanissa sana economy mainitaan vain kerran yhteiskunnan rahavarantojen hoidon yhteydessä ( $L$, XXIII, 4.) Tämä on sinänsä edistyksellistä, sillä sana economy otettiin käyttöön yleisenä valtion varakkuuteen ja resursseihin viittaavana käsitteenä vasta 1650 -luvulla. Kuten edellä on mainittu, Hobbes ei myöskään kirjoita runsassanaisesti taloudellisesta tuotannosta tai sisällöllisesti työstä. Hobbesia luettaessa on myös hyvä muistaa, että vaikka hän käyttää kohtalaisen paljon sanaa industry, hän ei varsinaisesti puhu teollisuudesta, vaan ihmisen taidoista ja neuvokkuudesta, sekä näihin liittyvästä ahkeruudesta, toiminnasta ja yritteliäisyydestä. Toisin sanottuna, talous, työ ja tuotanto eivät ole päällisin puolin Hobbesille kovinkaan merkittäviä asioita.

7) Järjestyksen ongelmaa on käsitelty etenkin sosiologisessa tutkimuksessa. Kysymys on liitetty erityisesti Talcott Parsonsin sosiologiaan, sillä Parsons esitti vaihtoehtoisen ratkaisun Hobbesin ongelmaan teoksessaan The structure of social action vuonna 1937. (Parsons 1937, 89-94.) On kuitenkin huomattava, että Parsonsin tulkinta Hobbesin filosofiasta ei ole täysin pätevä. Aiheesta tarkemmin katso Ellis 1971; Burger 1977 ja Kangas 121-139.

8) Haluan kiittää artikkelin kommentoinnista anonyymiä refereetä, Poliittinen talous -lehden toimituskuntaa sekä YTT Jouni Tilliä.

9) Olen suomentanut Hobbesin käyttämän termin multitude (lat. multitudo) termillä väkijoukko. Multitude voitaisiin kääntää myös termeillä väki tai rahvas. 
Nähdäkseni väkijoukko tulee kuitenkin lähimmäksi Hobbesin käsitettä. Väkijoukkoon ei Hobbesin mukaan koskaan liity poliittista subjektiviteettiä, toisin kuin kansaan. Väkijoukon ongelmasta Hobbesin filosofiassa, katso Jakonen 2013.

Io) Hobbesin luonnontilan käsite sai vaikutteita useista eri lähteistä. Poliittisessa filosofiassa "esivaltiollisesta" tilasta puhuttiin jo antiikin filosofiassa. Platon, Aristoteles ja Thukydides ovat todennäköisimmät kirjoittajat, joilta Hobbes on imenyt vaikutteita. Erityisesti Thukydideen merkitystä on usein korostettu (Ahrensdorf 2000). Toiseksi, luonnontila juontuu varhaismodernin ajan poliittisiin keskusteluihin kristinuskosta, jossa paratiisimyytti ja toisaalta ajatus perisynnistä ovat voimakkaita. Varhaismodernissa ja modernissa poliittisessa ajattelussa useat kirjoittajat viittaavat luonnontilaan ja kaikille Hobbesin jälkeisille filosofeille Hobbesin perintö on erittäin merkittävä. Tunnetuimpia luonnontilan teorioita Hobbesin lisäksi esittivät mm. John Locke ja Jean-Jacques Rousseau.

II) Hobbes käsittelee luonnontilaa kaikissa kolmessa poliittisessa pääteoksessaan. Katso Hobbes EL I; Hobbes DC I; Hobbes L, XIII.

I2) Leviathanissa Hobbes kirjoittaa: "...SOTAA ei ole vain yhteenotto tai taisteleminen, vaan ajanjakso, jolloin tahto käydä taisteluun on kyllin tunnettu. Siksi ajan käsite kuuluu mukaan sodan luontoon niin kuin se kuuluu sään luontoon. Sillä kuten huonon sään luonne ei ole sadekuurossa tai kahdessa, vaan monta päivää kestävässä taipumuksessa sateeseen, niin sodan luonne ei muodostu varsinaisesta taistelemisesta, vaan tunnetusta dispositiosta siihen koko sinä aikana, jolloin ei ole varmuutta päinvastaisesta. Kaikki muu aika on RAUHAA.” (L XIII, 8. s. 123.)

I3) Halu ja aversio liittyvät pääsääntöisesti vitaalisiin liikkeisiin (vital motion), jotka pitävät ruumiillista elämää yllä. Hobbes oli kuitenkin huomattavasti kiinnostuneempi sielullisista liikkeistä (animal motion), joita hän kutsuu myös tahdonvaraisiksi liikkeiksi (voluntary motion). Myös sielulliset liikkeet toimivat lähestyvän ja vetäytyvän liikkeen periaatteilla (appetite \& aversion), mutta huomattavasti monimutkaisemmin. Yleisesti, sielullisia liikkeitä voidaan kutsua tunteiksi (passions), kun taas vitaaliset liikkeet eivät kuulu tunteiden piiriin. ( $L$, VI.)

I4) Sisäänpäin kulkevia aistihavainnon aiheuttamia liikkeitä voidaan kutsua myös affekteiksi. Affektit eivät ole tunteita, vaan pikemminkin tuntemuksia ja 
vaikutuksia. Ne ovat esipersoonallisia ja jotain, mitä useat ihmiset jakavat yhtä aikaa (esimerkiksi auringon lämpö). Tunteet eli passiot ovat puolestaan reaktiota affekteihin, vaikka ne usein tunnetaankin ja ymmärretään mielenliikkeiden nopeudesta johtuen samoina liikkeinä. Passiot eivät kuitenkaan aina ole välittömiä reaktiota vaan ne voivat muodostua pitkän ajan kuluessa, hyvin monimutkaisissa ja -tasoisissa prosesseissa. Muistilla on siis tärkeä asema tunteiden syntymisessä. (L, VI.)

I5) Leviathanissa Hobbes kirjoittaa seuraavasti: "Pelko, johon ei liity käsitystä siitä miksi ja mitä pelätään, on PANIIKKIA; niin sitä kutsutaan niiden tarinoiden mukaan, joissa Pan sitä aiheuttaa, mutta todellisuudessa sillä, joka ensinnä pelkää näin, on aina jokin ajatus syystä, vaikka toiset seuraavat esimerkkiä, kun jokainen luulee kumppanien tietävän miksi. Ja sen vuoksi tämä passio ei satu kellekään muuten kuin tungoksessa tai väenpaljoudessa." (L, VI, 37. s. 69.)

I6) Mimesiksen suhteesta Hobbesin teoriaan pelosta ja hallinnosta, katso tarkemmin Jakonen 2013, 73-98.

I7) Hobbes määrittelee anarkian seuraavasti: “... anarkia, mikä merkitsee hallituksen puuttumista”. (Hobbes L, XIX, 2, s. 171.)

I8) Deborah Baumgold korostaa luottamuksen merkitystä Hobbesin filosofiassa (ks. Baumgold 2013). Hän ei kuitenkaan yhdistä luottamuksen käsitettä millään tavalla taloudelliseen toimintaan, joka on nähdäkseni sen olennainen ulottuvuus.

19) De Civessä Hobbes kirjoittaa seuraavasti: "Mutta ihmisten tulisi huomata, että niiden joilla ei ole perintöä ei tule ainoastaan työskennellä säilyäkseen hengissä, vaan myös taistella kyetäkseen työskentelemään.” (DC, XI, 9.) Suomennos MJ.

2o) De Civessä Hobbes kirjoittaa: "On jokseenkin selvää, että ne, jotka ajattelevat kantavansa koko yhteiskunnan taakkaa ovat alttiita kapinan lietsomiselle: ja ne, jotka kärsivät nykytilanteessa ovat tyytyväisiä mielenilmauksista (manifestum)." (DC, XII, 9.) Suomennos MJ.

2I) Biovallan käsitteen loi Michel Foucault kolmiosaisen Seksuaalisuuden historian ensimmäisessä teoksessa, Tiedon tahto (Foucault 2007, 177-211). Foucault'n termin sovellettavuudesta muihin kuin Foucault'n tarkoittamiin vallankäytön 
esimerkkeihin on keskusteltu paljon. Joidenkin mukaan biovallan käsitettä ei tulisi käyttää kuvaamaan muuta kuin 1800 -luvulla syntyvää, Foucault'n tutkimaa uutta vallan muotoa, joka keskittyy elämän hallintaan esimerkiksi väestötieteen avulla. Tietyistä anakronismin vaaroista huolimatta voidaan kuitenkin todeta, että esimerkiksi Hobbesin poliittisessa filosofiassa voidaan nähdä monia biovallan piirteitä, kuten useat tutkijat ovat korostaneet (ks. esim. Esposito 2008, 46; 56-59; Hull 2009, 137-143; Marshall 1996, 118-119; Pavlich 2010, 24-27.)

22) Hobbesin elämästä, katso Jakonen 2012. 